\title{
USES AND APPLICATIONS OF GEOREFERENCING AND GEOLOCATION IN OLD GARTOGRAPHIC AND PHOTOGRAPHIC DOCUMENT MANAGEMENT
}

\author{
Usos y aplicaciones de georreferenciación y \\ geolocalización en gestión documental cartográfica y \\ fotográfica antiguas
}

\author{
Jesús Cascón-Katchadourian, Antonio-Ángel Ruiz-Rodríguez and Jordi \\ Alberich-Pascual
}

Nota: Este artículo se puede leer en español en:

http://www.elprofesionaldelainformacion.com/contenidos/2018/ene/19_esp.pdf

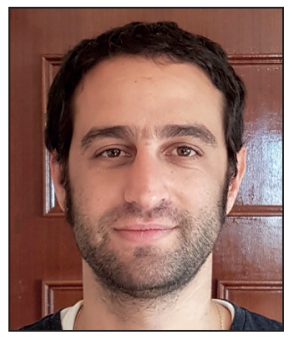

Jesús Cascón-Katchadourian has a degree in history and a degree in documentation from the University of Granada (UGR). He got a first national award for his documentation studies by the Ministry of Education, Culture and Sport. He began in the world of research by taking the Master in Information and Scientific Communication of the UGR. He is currently working on his doctoral thesis on ancient cartography, georeferencing and geolocation of historical photography, hired by the UGR as a university teacher training fellow (FPU). His field of study is the application of technology to historical heritage.

http://orcid.org/0000-0002-3388-7862

cascon@ugr.es

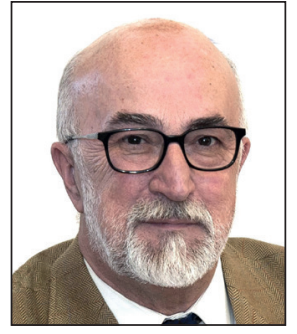

Antonio-Ángel Ruiz-Rodríguez has been a professor at the University of Granada (UGR) for more than thirty years. His research is based on traditional archivistics and, through studies on electronic documents and description standards, he focus in recent years on the recovery of photographic and cartographic documents. He currently directs 4 doctoral theses on photographic heritage and cartographic heritage. He directed the first doctoral thesis on photographic press funds at the $U G R$, marking a line of research that has been extended in six masters or doctorates from various universities. He is a professor of university school and university defender of the UGR.

http://orcid.org/0000-0002-3895-9546

aangel@ugr.es

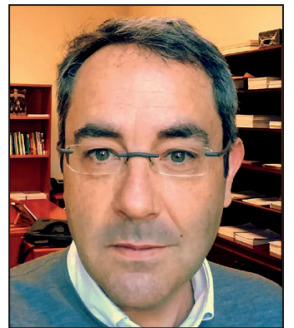

Jordi Alberich-Pascual, doctor from the University of Barcelona, is a university associate professor of Audiovisual Communication and Advertising at the Faculty of Communication and Documentation of the University of Granada. He has developed his research activity as an expert in digital aesthetics and communication in new media. He is the principal investigator of the Communicav research group (Audiovisual and Multimedia Creation, Production and Postproduction Processes), of the University of Granada.

http://orcid.org/0000-0001-6871-4614

jalberich@ugr.es

Universidad de Granada, Facultad de Comunicación y Documentación Campus Universitario de Cartuja Edificio Máximo. 18071 Granada, Spain

\begin{abstract}
The contemporary application of georeferencing and geolocation technologies has enabled the review and revitalisation of the method of presenting, disseminating, and making accessible cartographic and photographic documentation stored in archives, libraries, map libraries, museums, geographic institutes, and other key institutions. This article evaluates the interest and scope of document management of both technologies, analyses its contemporary application in cartographic and photographic management, and offers a systematised review of a significant number of practical cases from public and private institutions that have recently implemented their documentary heritage with success.
\end{abstract}




\section{Keywords}

Georeferencing; Geolocation; Documentation; Old cartography; Old photography.

\section{Resumen}

La aplicación contemporánea de tecnologías de georreferenciación y geolocalización ha permitido revisar y revitalizar la forma de mostrar, difundir y hacer accesible a la ciudadanía la documentación cartográfica y fotográfica almacenada en archivos, bibliotecas, cartotecas, museos, institutos geográficos y otras instituciones afines. El presente artículo evalúa el interés y el alcance para la gestión documental del uso de ambas tecnologías, analiza su aplicación contemporánea en la gestión cartográfica y fotográfica antiguas, y ofrece la revisión sistematizada de una serie significativa de casos prácticos de georreferenciaciación y geolocalización implementados recientemente con éxito por parte de instituciones públicas y privadas a su patrimonio documental.

\section{Palabras clave}

Georreferenciación; Geolocalización; Documentación; Cartografía antigua; Fotografía antigua.

Cascón-Katchadourian, Jesús; Ruiz-Rodríguez, Antonio-Ángel; Alberich-Pascual, Jordi (2018). "Uses and applications of georeferencing and geolocation in old cartographic and photographic document management". El profesional de la información, v. 27, n. 1, pp. 202-212.

https://doi.org/10.3145/epi.2018.ene.19

\section{Introduction}

In the last few decades the extensive use of GPS navigation systems through the widespread use of the Internet in mobile phones, and thus the numerous multimedia applications that make use of geolocation technologies, has increased the use of maps exponentially, and with it cartographic document management (Jiménez-Pelayo; Bonachera-Cano, 2001; Beltrán-López, 2012). All these technologies and the primary uses for which they were designed have allowed us to both review and revitalise the way of presenting, disseminating and making the cartographic and photographic documentation stored and digitised in archives, libraries, map libraries, museums, geographic institutes and other institutions publicly accessible (Cascón-Katchadourian; Ruiz-Rodríguez, 2016).

Alongside many other possible uses, georeferencing technologies applied to cartographic sources allow us to convert the image from the digitalisation of old maps (Crespo-Sanz; Fernández-Wyttenbach, 2011) into an interactive layer that can be displayed in a Geographic Information System (GIS) through a web browser or a mobile app (Maptiler, 2017). This is possible by assigning geographic coordinates to an element that did not have them, and embedding it in related applications of widespread universal use such as Google Maps. Geolocation technologies applied to old photographic collections allow us to discover where the images were taken, find out what is shown in many of them and, above all, facilitate the user to search through a map using geographic coordinates of the photographs.

The present research focuses precisely on these two technologies: georeferencing and geolocation, with the objectives of assessing the interest in and scope of the document management of both, analysing their contemporary application in the old cartographic and photographic management, and reviewing a significant series of practical cases recently implemented by public and private institutions in their documentary heritage.

\section{Methodology}

The discursive approach of this work is based on the increasing adoption of georeferencing and geolocation technologies over the last decade by institutions with documentary collections, with the aim of optimising their task of showing, disseminating and making public heritage accessible to all. In this paper we review this adoption process and evaluate its consequences for contemporary document management.

Consequently, the present study has combined basic and applied research, descriptive and field specific. After indexing the bibliography on all the subjects related to georeferencing and geolocation, on cartography and old photography and on the new ways of displaying it, as well as the GIS and how to georeference and geolocate, we have proceeded to carry out the field work on recent institutional experiences with these tools to show their historical documentary heritage, and their analysis and comparative study.

In our choice of cases we wanted to illustrate the varied catalogue of heritage institutions, and of contemporary georeferencing and geolocation examples of existing document collections, organising and standardising the results based on the establishment of four general types of uses:

1) Collaborative cartographic georeferencing.

2) Geographical search engines for cartography.

3) Mobile geolocation of old photographs.

4) Other uses and applications, among which we highlight the following:

4a) Machine-readable information.

4b) Web mapping of photographs and stories.

Finally, we offer the results achieved in a synoptic summary table of each of the selected types, organised by the year each began, advantages of and motivations for its use, the most notable programs and institutions, and the lines of work in development for each of the selected types. 


\section{Georeferencing and geolocation in contempo- rary cartographic and photographic document management}

Although both technologies, georeferencing and geolocation, and the terms that denote them have their origin in the field of Geography (Ortiz, 2016), their recent popularisation is linked to the appearance and massive use over the last decade of websites, apps and social networks that offer services depending on the user's situation and what surrounds them, such as

- Foursquare (which recommends places near the user's position and shows where their contacts are);

- TripAdvisor (which shows nearby hotels and restaurants on a map and ranks them)

- GoogleMaps (which as a result of position and route, warns of traffic jams, roadblocks or hazards);

- Wallapop (which takes into account the user's location and that of the vendors to show relevant products close to the user); and

- PokemonGo (the well-known augmented reality game based specifically on geolocation technologies), among others.

Beyond the specified uses and applications, linked mostly to marketing or videogames, georeferencing is today an important area of study within the field of cartography (Witmer et al., 2006; Hill, 2009; Long et al., 2016). It is a fundamental element of ancient cartography, as it allows us to accurately reconstruct the geographical situation of plans on a large scale and without projections ${ }^{1}$. Its use allows to revitalise and give new purpose to numerous and diverse ancient cartography that remains in archive deposits, libraries and cultural centres.
In cartography, georeferencing processes follow the identification of homologous points in the coordinate systems of two documents of different origin:

1 ) the raster coordinates system of a digitised ancient map without geographic coordinates; and

2 ) the coordinates system of a support map or reference cartography (Dávila-Martínez; Camacho-Arranz, 2012).

The process usually consists of establishing a common location which both the reference cartography and the cartography without georeferencing share with certainty, and that has been maintained over time (geographical features, monuments, streets), thus indicating to the SIG that those two points in both maps are geographically the same (Figure $1)$; the more control points which are created, the more accurate the georeferencing will be (Arcgis, 2013; 2016).

\section{Georeferencing revitalizes and yelds new applications to cartography deposited in archives, libraries and cultural centres}

Georeferencing, with the help of digitisation and web publication, facilitates access for non-expert users to geographical, heritage, urban or environmental information of interest. This technique allows us to embed the old map in current maps such Google Maps, Bing Maps or similar, and by means of transparency sensors, compare them, making possible the development of evolutionary historical studies by urbanists, historians or architects on how a city, a state or a territory has evolved.

Geolocation consists of determining the precise situation occupied by a given object in space, according to its latitude, longitude, and height coordinates (Beltrán-López,

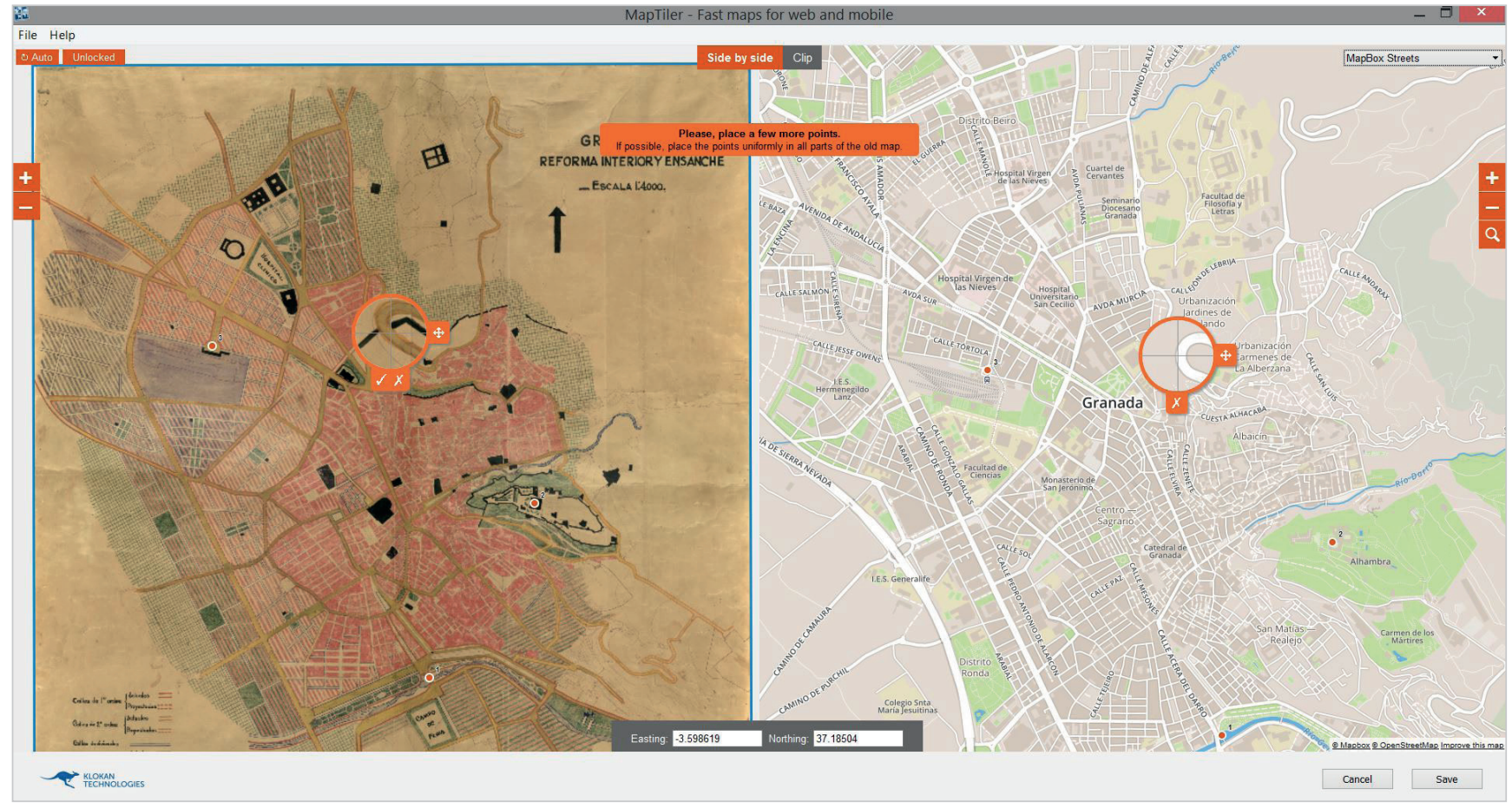

Figure 1. Georeferencing process allocating control points 
2015). The great importance achieved by this is due to the large number of different functions and services that can be offered after placing an object in the world, and obtaining real-time information about the context relative to its geographical position (Ortiz-Ocaña, 2016).

Applied to the field of audio-visual heritage, geolocation allows to geographically locate old photographs belonging to an institution, as well as any other type of paintings, drawings, brochures or historical posters. Likewise, it allows the optimisation of search engines of photographic collections: in the case of old photographs, rather than by the author or by the title of the photograph, the users carry out searches by theme or, above all, places. If the photographs have been previously geolocated, their access and retrieval will be significantly simplified by a map search, for example. This would also facilitate the study of the evolution of a place or areas of a city through its photographs, confirming the benefits of such techniques and programs in relation to old cartography and photography.

\section{Geolocation allows to geographically} locate old photographs and optimize search systems, facilitating studies of the evolution of a place or areas of a city

Individually, combined, or complemented with other emerging technologies such as searching by time filters, periods, type of photographic or cartographic technique or others (Southall; Pridal, 2017), there are numerous institutional uses of georeferencing and geolocation of cartographic document and photographic collections, which have attained results of great interest that deserve the attention of the scientific community:

- applications that, according to the user's position, show old photography or cartography nearby;

- sending alerts to mobile devices in proximity to one of these;

- graphic simulations to experience a "walk" on a seventeenth-century map;

- transparency sensors that allow us to compare the context of an old photograph on our mobile with the current reality, among many others, and which we have set out in the following section.

\section{Review of experiences, uses and applications}

Here we demonstrate the results of our analysis of experiences, uses and contemporary applications of georeferencing and geolocation of existing cartographic and photographic documentary collections, based on the establishment of four general types with full present-day significance:

1) Collaborative cartographic georeferencing.

2) Geographical search engines for cartography.

3) Mobile geolocation of old photographs.

4) Other uses and applications.

\subsection{Collaborative cartographic georeferencing}

In collaborative georeferencing, the users of the institutions with cartography collections are those who perform online web georeferencing. When users access the old cartogra- phy section, they are offered the option to participate and collaborate in their georeferencing from a random selection of maps. An explanatory video usually describes the process and the user can proceed without the need to download any complex program, performing all of the work through the web browser. Subsequently the institution reviews the work done. In this way, the institution tries to build loyalty and gratify the user by offering statistics of georeferenced maps for each of the collaborators.

The collaborative georeferencing of old cartography is a modern process carried out, among others, in:

Public libraries:

- New York Public Library (NYPL)

- Moravian Library (Czech Republic)

- British Library

- National Library of Scotland

Public archives:

\section{- National Archives of the Netherlands}

Map libraries and geographic institutes:

- Institut Cartogràfic i Geològic de Catalunya (ICGC)

Universities:

- Harvard

- Stanford

Private collections

- David Rumsey.

The use of tools and systems of collaborative georeferencing is very useful to cultural institutions that have hundreds or thousands of maps, plans and cartographic documents, and which through mass collaboration (crowdsourcing) can meet the objectives of:

a) involving the citizens and reuse the intelligence of the community;

b) enriching their collections with metadata, descriptions, comments or geodata;

c) allowing the discovery of new knowledge;

d) establishing new channels of trust and communication with users; as well as

e) encouraging a public spirit of responsibility for heritage collections (Holley, 2010).

Among the various existing programs for collaborative georeferencing, two of them stand out for their excellence and breadth of use:

\section{- Map Warper, in North America; \\ - Georeferencer, in Europe.}

The first one, Map Warper, was inspired by the previous Metacarta's Map Rectifier, and developed on its foundations by Tim Waters in 2009, to be used with OpenStreetMap (Map Warper, 2017). This program caught the attention of the New York Public Library and the universities of Harvard and Stanford (Ramos, 2016) which then used it in their own projects New York Public Library's Map Warper (New York Public Library, 2017), Harvard University's WorldMap WARP (Harvard, 2017) and Stanford Map Warper. The New York Public Library itself currently supports the original 
program, and is the institution that has given the prestige which Map Warper holds, being the pioneer institution in collaborative georeferencing, currently reaching more than 10,000 georeferenced maps with its own version of Map Warper (New York Public Library, 2017).

The second program, Georeferencer, began its development in 2008 by the software engineer, consultant and founder of the company Klokan Technologies $\mathrm{GmbH}$, Petr Pridal, and the Moravian Library of Brno as part of the OldMapsOnline projects (OldMapOnline, 2017 ) and Temap (Temap, 2012). In the subsequent 4 years it was implemented in 5 institutions (Fleet; Kowal; Pridal, 2012):

- Moravian Library (2009)

- Nationaal Archief (2010);

- National Library of Scotland (2010);

- The British Library (2011) (Figure 2);

- Institut Cartogràfic de Catalunya (2012).

Georeferencer is based on the open source GDAL, Proj4 and MapServer applications. It also allows online collaborative georeferencing, which is a much cheaper way of georeferencing maps than georeferencing by internal staff of the institutions. Unlike MapWarper, it is not based on the upload of images to a website, but uses images that are already on the web servers of the libraries by applying a zoomed-in view through tiles, using the Web map tile service protocol. It is also easy to implement, since no new installation or maintenance of local software is required (Fleet; Kowal; Pridal, 2012).

\subsection{Geographical search engines for cartography}

From the end of the first decade of this century, the emergence and growing development of new web technologies, APIs (application programming interfaces), the geospatial progress of the open source movement (Open Source Geospatial Foundation), in particular the appearance of Google Maps (2005), and Google Earth (2005), enabled the deve- lopment of web-based graphical user interfaces (GUI) with map components in a simple and cost-effective process, and with it the subsequent emergence and boom of a large number of web portals of cartographic map searches, such as Opengeoportal, Digmap, Cartomundi, Maps of Australia, Kartenportal, David Rumsey Map Collection, Cartocat, and OldMapsOnline, among others.

The motivation to develop a geographic cartography search engine is to overcome the dissatisfaction with conventional catalogues or opacs with free text search in old cartography: an arduous process, which takes a large amount of time, and usually yields a small success rate, in addition to the difficulties of homonymy and geographical names that change over time (Oehrli et al., 2011). On the contrary, the indexing and search of maps by geographic coordinates facilitates the retrieval of the information, the results are precise, unique and constant over time, the applications are intuitive and easy to use, they do not require lengthy previous ex-

Table 1. Summary table on collaborative cartographic georeferencing

\begin{tabular}{|l|l|}
\hline \multicolumn{2}{|c|}{ Collaborative georeferencing } \\
\hline Start year & 2009 \\
\hline Advantages & Georeferencing a multitude of maps with limited funds; Involvement of citizens \\
\hline $\begin{array}{l}\text { Featured } \\
\text { programs / institutions }\end{array}$ & Georreferencer (Moravian Library, British Library) and MapWarper (NYPL, Harvard). \\
\hline On-going lines of work & $\begin{array}{l}\text { Collaborative georeferencing of collections of drawings, prints, or posters; Georeferencing of textual documents (Asocia- } \\
\text { ción Argentina de Humanidades Digitales, 2017); Automatic georeferencing through pattern recognition. }\end{array}$ \\
\hline
\end{tabular}




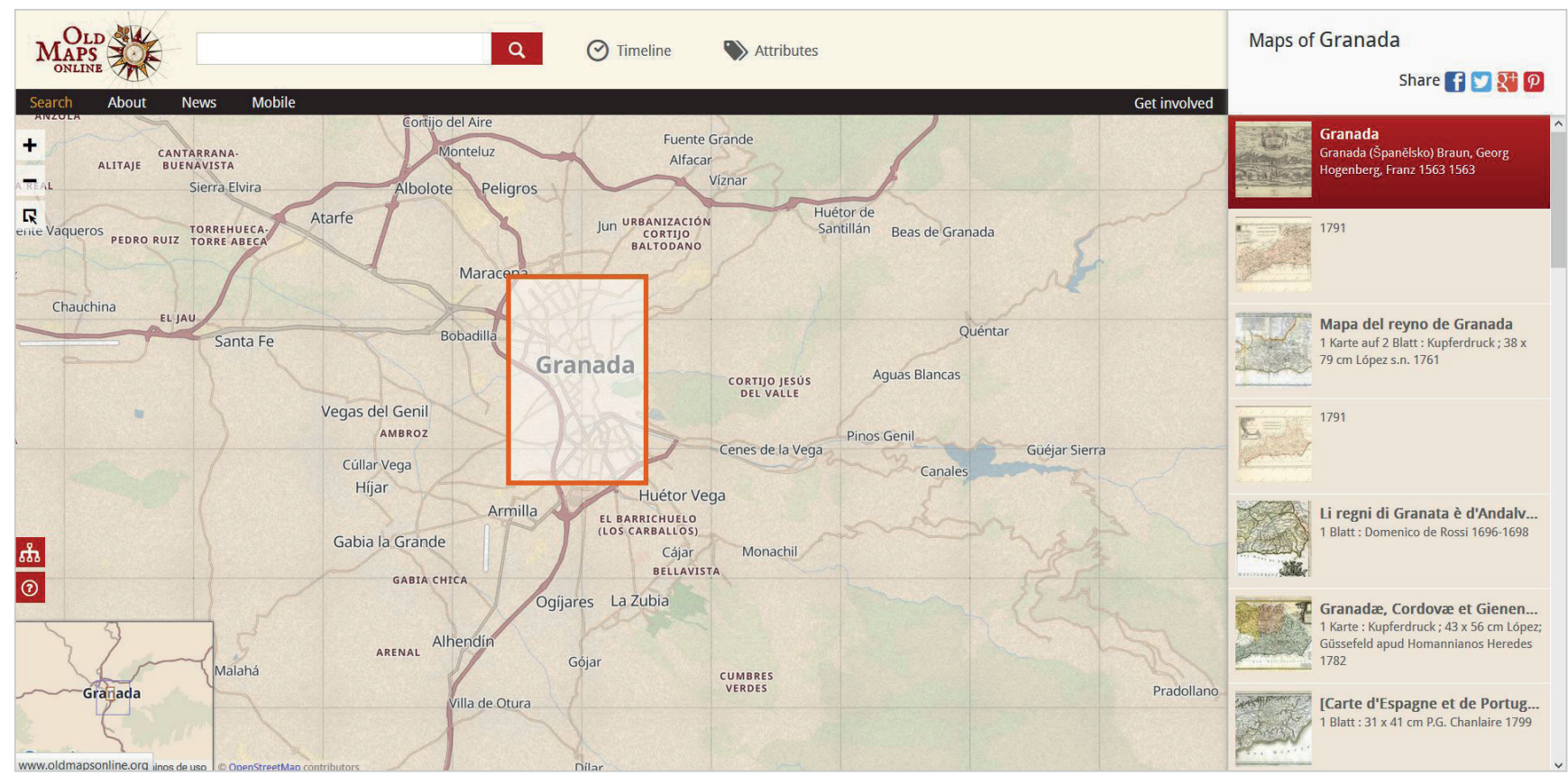

Figure 3. Search interface of OldMapsOnline. Source: OldMapsOnline http://www.oldmapsonline.org

planation, and very specifically, they offer greater speed in obtaining the results required by the users.

Prominent in this area is the search algorithm called $\mathrm{Ma}$ pRank Search, which arose in response to the needs of Kartenportal in 2008, where it was installed for the first time. It was developed by the company Klokan Technologies and its first stable version was launched in September 2010. It is based on an extended spatial similarity function that compares two regions:

- the region covered by the cartographic material; and

- the region covered by the search rectangle of the user.

Both can be the same, be overlapping, one may contain the other or vice versa, or they may be dissociated (Larson; Frontiera, 2004). There are also filters for the date and map scale, as well as a full-text search to generate a final ranking, where the most relevant document is located at the top of the list (Oehrli et al., 2011).

MapRank Search is used by numerous portals and cartographic search engines, such as the aforementioned Kartenportal, the David Rumsey Map Collection, as well as the OldMapsOnline portal (Figure 3). We want to highlight this last project, which started in 2012, as a collaboration between Klokan Technologies and the British GIS project of the University of Portsmouth, United Kingdom (JISC, 2017), which today is the most outstanding portal in this field, optimised with search engines as GeoSEO, powered with Linked Data (OldMapsOnline, 2017b), and which currently offers nearly 400,000 georeferenced maps. OldMapsOnline also stands out for its ease of use, the large number of top level institutions that have made their extensive cartographic heritage accessible, such as the National Library of Scotland, the David Rumsey Map Collection, the NYPL Map Division, the British Library, the Harvard Library, the Institut Cartogràfic de Catalunya, and the Museu Geològic de Catalunya, among others (OldMapsOnline, 2017b).

\section{Some applications make graphic simula- tions to experience a "ride" over an old map}

\subsection{Mobile geolocation of old photographs}

In this third type we group and analyse the possibilities presented by the mobile phone to receive alerts of old photographs or other related documentation surrounding the user, and to direct the user towards these. Combined appropriately with augmented reality technologies, these applications allow an urban historical heritage experience complemented by overlapping and comparison with old photographs.

Table 2. Summary table on geographic search engines for cartography

\begin{tabular}{|l|l|}
\hline \multicolumn{2}{|c|}{ Geographic search engines for cartography } \\
\hline Start year & Early 80s. The first large scale one in 2008 \\
\hline Advantages & Improves the retrieval of information of old cartography; Easy to use, intuitive \\
\hline Featured programs / institutions & $\begin{array}{l}\text { MapRank Search (Kartenportal, David Rumsey, OldMapsOnline). OldMapsOnline (NYPL, David Rumsey, NLS, } \\
\text { British Library) }\end{array}$ \\
\hline On-going lines of work & $\begin{array}{l}\text { Greater number of institutions in the same search engine; Partnerships with Europeana; Map search by } \\
\text { pattern recognition }\end{array}$ \\
\hline
\end{tabular}




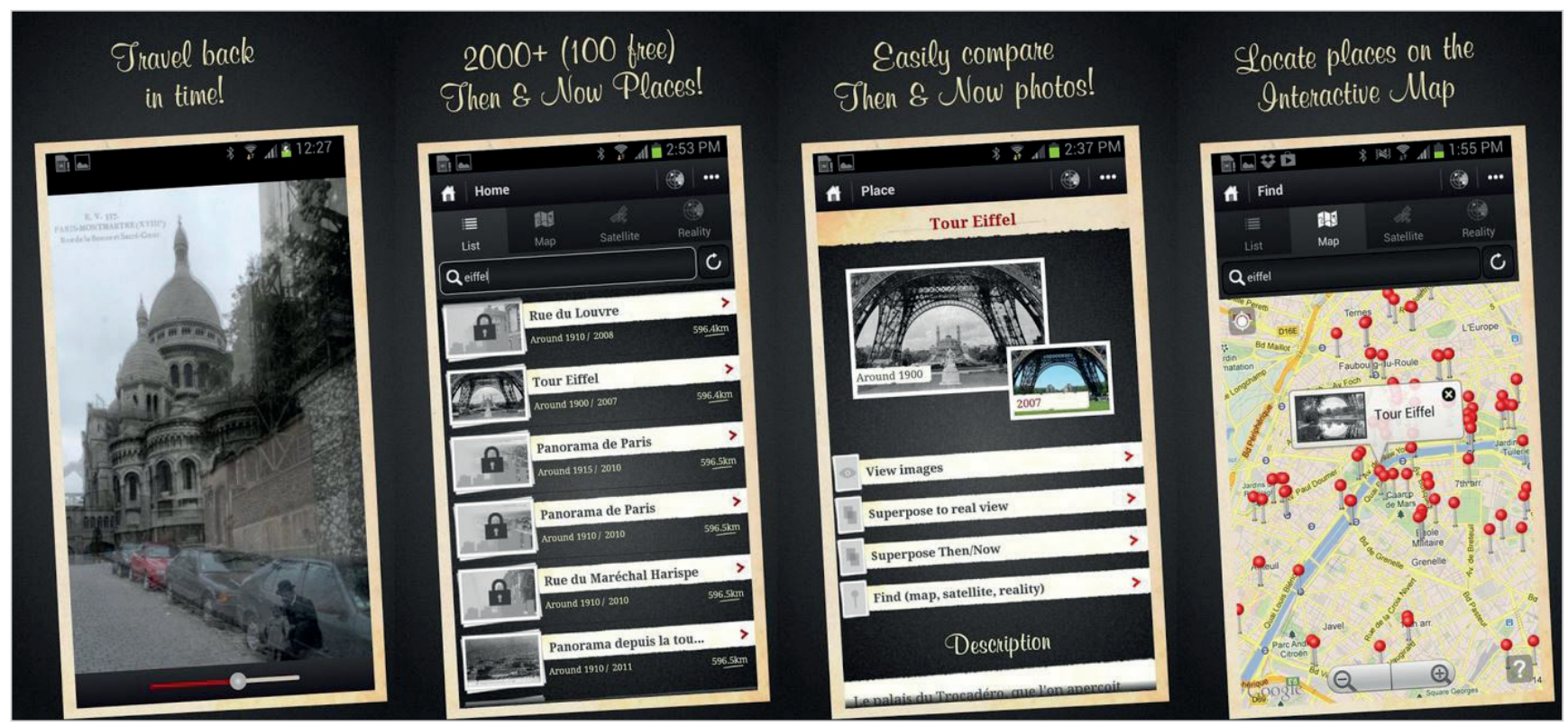

Figure 4. Application "Paris. Yesterday and today" of MaVille Avant. Source: Google Play Ma Ville Avant https://play.google.com/store/apps/details?id=com.rasap.parisavant.free\&hl=es_4

Despite its majority approach to a "flâneur" user, i.e. a user who walks and wanders around the city, sometimes aimlessly, without objective, open to all the deviations and impressions that arise, some applications also allow this comparison of the past and the present to be made from home, since in the database there are old and current photographs of the same position, thus making this heritage accessible to people with reduced mobility.

In opposition to the significant public and institutional base of the two previous groups dedicated to collaborative georeferencing, and to geographical search engines, the impulse of mobile geolocation applications and combination of augmented reality and old photography, comes more usually from the private world, starting from a freemium model. We highlight the applications of the companies Carbonbyte ("Timelinetrip"), and especially of MaVille Avant ("Paris. Yesterday and today"), a pioneering and outstanding company in this sector.

MaVille Avant has applications with the same format for cities such as Paris, Barcelona, Nantes, Metz, Vancouver, Montreal, and Tampa (Google Play, 2017). The first of them, launched at the end of 2011, was "Paris. Yesterday and today" (Figure 4), which obtains historical and current photographs from the website ParisAvant.com, dedicated to the daily publication of a 100 year old photo of a place in Paris taken from a collection of postcards, alongside a present-day photo of the same place taken from the same an- gle, as well as the history of the place (Botton, 2014).

MaVille Avant applications allows the user:

- to configure the distance of notifications in the vicinity of an old photograph;

- leave the app searching in the background while the user uses the mobile for other functions;

- quickly link with social networks to share an old or recent photograph; and very specifically

- to show in a map the numerous available old photographs, carry out their geographic search, geolocate them, and direct the user to this precise location to enjoy the experience and present-day contrast.

The visualisation of the results is very complete, being able to visualise:

a) in map mode (satellite or map from Google Maps) where each geolocated photograph is highlighted with a red icon; or b) in list format, showing the results as a thumbnail of the photograph, title, date and distance from the user's position.

It also allows a traditional textual search that acts as a filter of all the results. In the visualisation of each result, the title is offered next to two photographs: the old one in a larger size, and the current one slightly smaller and superimposed in one margin, as well as the date in which both were taken. Broad descriptions of each result are also offered, describing the place, the history, and anecdotes in a casual style in order to connect with a large number of users.

Table 3. Summary table on mobile geolocation of old photographs

\begin{tabular}{|l|l|}
\hline \multicolumn{2}{|c|}{ Mobile geolocation of old photographs } \\
\hline Start year & 2011 \\
\hline Advantages & Improve the information retrieval in old photography; Easy to use, intuitive \\
\hline Featured programs / institutions & "Paris. Yesterday and today" (MavilleAvant), "Timeline trip" (Carbonbyte) \\
\hline On-going lines of work & $\begin{array}{l}\text { Apps with more scientific and rigorous descriptions; Filtering of time, or according to location; Incorporation } \\
\text { of collaborative geolocation. }\end{array}$ \\
\hline
\end{tabular}




\begin{tabular}{|l|l|}
\hline \multicolumn{2}{|c|}{ Machine-readable information } \\
\hline Start year & 2012 \\
\hline Advantages & Provide interactive maps; Multiple possibilities in semantic web services \\
\hline Featured programs / institutions & Map-Vectorizer. New York Public Library \\
\hline Ongoing lines of work & $\begin{array}{l}\text { Collaboration between large institutions; Creation of software that allows OCR with maps; Integration with } \\
\text { historical photographs }\end{array}$ \\
\hline
\end{tabular}

\subsection{Other uses and applications}

The uses and previous applications do not exhaust the possibilities of georeferencing and geolocation in the management of audio-visual heritage, which in the fields of machine-readable information, and the web mapping of photographs and stories, has other uses and significant applications.

\subsubsection{Machine readable information}

Once a map has been scanned and georeferenced, the next challenge is to try to make that information machine-readable, so that all of the information contained in the map through legends, street names, numbers, restaurant locations, monuments, etc., can become interactive, and so allow the user to search geographically and textually, or easily relate it to other types of information of the time such as old images and photographs.

At the forefront of this line of work is The New York Public Library, with its project The New York City Historical GIS Project (New York Public Library, 2012). The phases of the process are:

- scanning;

- geo-rectification;

- trimming the frames of the maps so that only the geographic information can be seen (making it possible to join the maps of an atlas);
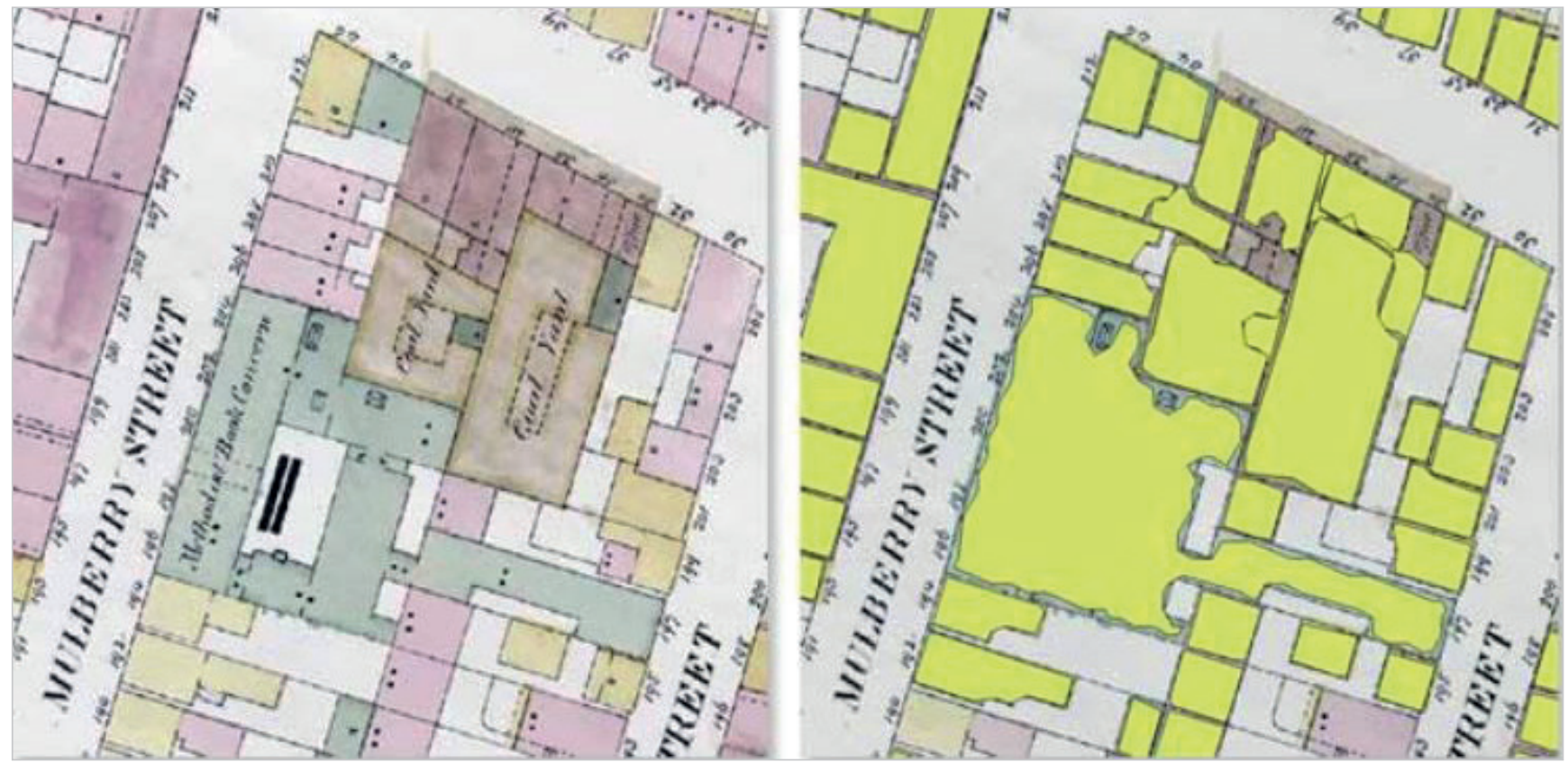

digitisation or tracing using Map-Vectorizer (Figure 5) to make maps machine-readable, allowing its data to be collected, extracted, analysed and be part of the semantic web relating them over time (Arteaga, 2013).

There are several incentives and advantages of being able to make information contained in old cartography computer-readable. According to the project managers in the NYPL, these include the ability to recover lost attractions, discover of the purpose of old establishments, or see a street in 3D with old photographs, among other interesting uses (New York Public Library, 2012b).

\section{OldMapsOnline stands out for its ease of} use and the nearly 400,000 georeferenced maps available

\subsubsection{Photographies and stories web mapping}

Another use and significant application is the aforementioned web mapping of photographs and histories in geolocation portals. These aim for the users themselves to upload their old photographs, normally from private family collections. Usually each user or organisation has its own space to upload their photographs and descriptions, so these portals have a very important social component, as they are sharing their personal stories. The web portals SepiaTown and Historypin stand out as examples.

Figure 5. Map vectorizer, an OCR for maps. Source: New York Public Library https://github.com/nypl-spacetime/map-vectorizer 


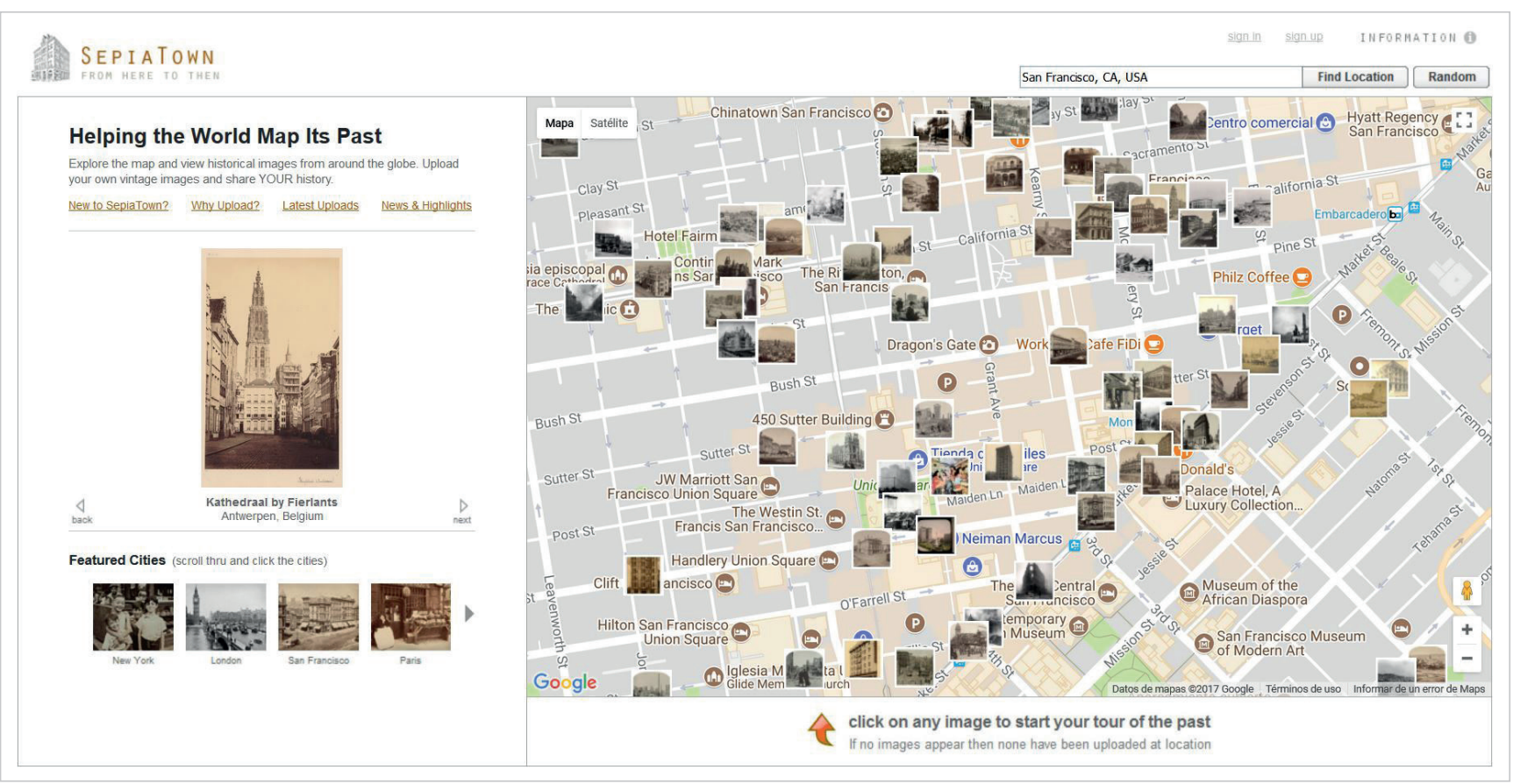

Figure 6. Sepia Town, search by map with thumbnails images. Source: Sepia Town http://www.sepiatown.com/inde

SepiaTown is the result of the union of three fans of old photography, whose jobs are related to this field and who dedicate free time to this project (SepiaTown, 2017). It started in early 2010 and soon afterwards many anonymous users and important public institutions such as the New York Public Library, Powerhouse Museum of Sydney (Australia), and San Francisco Public Library participated in the project. An outstanding feature is the attractive search by means of a map using thumbnails of the images (Figure 6). Each result provides the option to compare the image with a present-day image via Google Street View. It is a functional solution, which allows the user not only to observe the present-day photography, but also the surroundings, thus helping to understand the images through their context or environment.

Historypin, one of the projects of the non-profit organisation Shift (Shift, 2017) that began its journey with the initial support of Google in 2011 (Shift, 2017b), maintains the same collaborative strategy of showing old photography which has been geolocated by the users of the platform through a map, which we have seen in SepiaTown. A large number of cultural institutions, civil organisations, town halls and community groups have included their historical photographic collections, to date offering more than 300,000 stories (old photographs), part of more than 27,000 projects, built by a community of more than 80,000 users (Historypin, 2017). It also uses Google Street View, allowing the user to upload photographs to their profile, and share them on social networks, within the framework of building a knowledge community, capable of optimising and suggesting a more suitable location or a date.

The next challenge is to try to make the information readable by machine, so that all the information contained in the map (legends, street names, numbers, location of restaurants, monuments) can become interactive

\section{Conclusions}

The emergence and implantation of georeferencing and geolocation technologies has exponentially increased the social communication of old cartographic and photographic documentation.

Table 5. Summary table on the web mapping of photographs and stories

\begin{tabular}{|l|l|}
\hline \multicolumn{2}{|c|}{ Web mapping of photographs and stories } \\
\hline Start year & 2010 (Sepia Town) \\
\hline Advantages & $\begin{array}{l}\text { It allows collaborative geolocation; The user can see photographs of different topics and institutions; Intui- } \\
\text { tive searches by place }\end{array}$ \\
\hline Featured programs / institutions & Sepia Town and Historypin \\
\hline On-going lines of work & $\begin{array}{l}\text { Old photographs can be viewed in 3D mapping; Immersion and graphic simulation of what a street or } \\
\text { urban space was like in the past }\end{array}$ \\
\hline
\end{tabular}


The review of the uses and applications of both technologies developed by prominent public and private institutions over the past decade to their heritage collections, has allowed us to verify the contemporary revitalisation of the dissemination and accessibility of maps and old photographs stored in archives, libraries, map libraries, museums or geographical institutes.

Also, the four types of georeferencing and geolocation experiences in cartographic and historical photography document management that we have organised in the course of our research (collaborative cartographic georeferencing, geographical search engines for cartography, mobile geolocation of old photographs, and other uses and experiences such as machine-readable information, or the web mapping of photographs and stories), currently exhibit a significant implantation and vitality in the field of artistic and audio-visual heritage management, with various ongoing lines of work and development.

In the case of collaborative cartographic georeferencing processes, despite being a fledgling type which emerged less than 10 years ago, we emphasise its full contemporary institutionalisation, as a result of its use and implementation in numerous international reference cultural institutions, such as The British Library, The National Library of Scotland, The New York Public Library, The National Archives of the Netherlands, Harvard University and Stanford University, among others.

In the case of geographic search engines for cartography, despite previous applications for the retrieval of this type of documentation since the very early stages of the Internet, it has not been until the last decade that they have acquired a volume and scope of full social significance, able to find, organise and offer huge amounts of maps as well as algorithms to retrieve them, highlighting MapRank Search and OldMapsOnline as featured portals in the international scenario.

In relation to the mobile geolocation of old photographs, the development, recent popularisation, and normal use of apps designed for this purpose in mobile devices by the public, and especially tourists, travellers and visitors from other cities, has brought numerous advantages for the recovery of the historical memory of a place from old photographs. In this sense, companies such as Ma Ville Avant and Carbonbyte do a great job of disseminating historical heritage by relating and contrasting images of the past with their present-day reality.

Finally, the review of other uses and applications has allowed us to verify how machine-readable information or the web mapping of photographs and stories are in full development at the moment, defining two future lines capable of optimising search experiences and retrieving cartographic and old photographic information.

\section{Note}

1. When you represent on a flat surface something that is not (the world has a spherical shape) errors occur. To make these as small as possible, the projections are used, although in old cartography they are unusual. The georeferencing would literally stretch the digitized image of the old plane and make it more accurate.

\section{References}

Arcgis (2013). "Ayuda de ArcGIS 10.1. ¿Qué son los datos ráster?". ArcGIS Resources.

http://resources.arcgis.com/es/help/main/10.1/index.htm/

Arcgis (2016). "Principios básicos de georreferenciación de un dataset ráster". ArcMap.

https://goo.gl/CRUk6q

Arteaga, Mauricio-Giraldo (2013). "Historical map polygon and feature extractor". In: Proceedings of the $1^{\text {st }}$ ACM SIG Spatial intl workshop on map interaction, pp. 66-71, ACM. https://doi.org/10.1145/2534931.2534932

Asociación Argentina de Humanidades Digitales (2017). Proyecto Lit-e-map. Mapeos electrónicos de la literatura, Abril 19.

http://dayofdh2017.linhd.es/aahd/2017/04/19/proyectolit-e-map-mapeos-electronicos-de-la-literatura

Beltrán-López, Gerson (2012). Geolocalización y redes sociales. Bubok. ISBN: 9788468617626

Beltrán-López, Gerson (2015). "La geolocalización social”. Polígonos. Revista de geografía, v. 27, pp. 97-118.

https://doi.org/10.18002/pol.v0i27.3290

Botton, Frédéric (2014). ParisAvant.com. http://parisavant.com

Cascón-Katchadourian, Jesús-Daniel; Ruiz-Rodríguez, Antonio-Ángel (2016). “Descripción y valoración del software MapTiler: del mapa escaneado a la capa interactiva publicada en la Web". El profesional de la información, v. 25, n. 6, pp. 970-978.

https://doi.org/10.3145/epi.2016.nov.13

Crespo-Sanz, Antonio; Fernández-Wyttenbach, Alberto (2011). “¿Cartografía antigua o cartografía histórica?”. Estudios geográficos, v. 72, n. 271, pp. 403-420.

https://doi.org/10.3989/estgeogr.201115

Dávila-Martínez, Francisco-Javier; Camacho-Arranz, Elena (2012). “Georreferenciación de documentos cartográficos para la gestión de archivos y cartotecas: "propuesta metodológica"'”. Revista catalana de geografía, v. 17, n. 46.

http://www.rcg.cat/articles. php?id=252

Fleet, Christopher; Kowal, Kimberly; Pridal, Petr (2012). "Georeferencer: Crowdsourced georeferencing for map library collections". D-Lib magazine, v. 18, n. 11/12.

https://doi.org/10.1045/november2012-fleet

Google Play (2017). Ma Ville Avant.

https://play.google.com/store/apps/developer?id=MaVilleAvant

Harvard (2017). WorldMap WARP.

http://warp.worldmap.harvard.edu

Hill, Linda (2009). Georeferencing: The geographic associations of information. MIT Press. ISBN: 9780262083546

Historypin (2017). About.

https://about.historypin.org/about

Holley, Rose (2010). "Crowdsourcing: How and why should libraries do it?". D-Lib magazine, v. 16, n. 3/4. https://dx.doi.org/10.1045/march2010-holley 
Jiménez-Pelayo, Jesús; Bonachera-Cano, Francisco-José (2001). "Recursos de información cartográfica en internet". En: Jiménez-Pelayo, Jesús; Monteagudo-López-Menchero, Jesús. La documentación cartográfica: tratamiento, gestión y uso. Huelva: Universidad de Huelva, pp. 221-262. ISBN: 84 95699036

http://eprints.rclis.org/14083

JISC (2017). "We're a membership organisation, providing digital solutions for UK education and research". JISC. https://www.jisc.ac.uk

Knutzen, Matt (2012a). "The New York City historical GIS project". NYPL labs, 13 June.

https://www.nypl.org/blog/2012/06/13/nyc-historical-gisproject

Knutzen, Matt (2012b). "Unbinding the Atlas: Working with digital maps". NYPL Labs, 10 January.

https://www.nypl.org/blog/2012/01/10/unbinding-atlasworking-digital-maps

Larson, Ray; Frontiera, Patricia (2004). "Spatial ranking methods for geographic information retrieval (GIR) in digital libraries". En: Heery, Rachel; Lyon, Liz (eds.). Research and advanced technology for digital libraries: $8^{\text {th }}$ European conference: Proceedings ECDL 2004, pp. 45-56.

http://cheshire.berkeley.edu/ECDL2004_preprint.pdf

https://doi.org/10.1007/978-3-540-30230-8_5

Long, Tengfei; Jiao, Weili; He, Guojin; Zhang, Zhaoming (2016). "A fast and reliable matching method for automated georeferencing of remotely-sensed imagery". Remote sensing, v. 8, n.1.

https://doi.org/10.3390/rs8010056

MapTiler (2017). "Prepare and publish your own zoomable maps". MapTiler.

http://www.maptiler.com/features

Map Warper (2017). "About". Map Warper.

http://mapwarper.net/about

New York Public Library (2017). NYPL Map Warper.

http://maps.nypl.org/warper
Oehrli, Markus; Pridal, Petr; Zollinger, Susanne; Siber, Rosi (2011). "MapRank: Geographical search for cartographic materials in libraries". D-Lib magazine, v. 17, n. 9/10.

https://doi.org/10.1045/september2011-oehrli

OldMapsOnline (2017a). "Discovering the cartography of the past". OldMapsOnline.

http://www.oldmapsonline.org

OldMapsOnline (2017b). "About. The search engine for historical maps". OldMapsOnline.

http://www.oldmapsonline.org/about

Ortiz-Ocaña, Francis (2016). “Geolocalización vs georreferenciación”. Ubikua. Geolocalización, realidad aumentada y LBS. http://www.ubikua.com/2016/08/geolocalizacion-vsgeorreferenciacion.htm/

Ramos, Noelia (2016). "Georeferenciación de cartografía antigua con la ayuda de la comunidad: la experiencia de la Cartoteca de Cataluña (ICGC)". Revista catalana de geografía, v. XXI, n. 53.

http://www.rcg.cat/articles.php?id=353

SepiaTown (2017). "About us". SepiaTown. http://www.sepiatown.com/about

Shift (2017a). "About". Shift.

http://shiftdesign.org.uk/about

Shift (2017b). "Historypin. Preventing social isolation". Shift. http://shiftdesign.org.uk/products/historypin

Southall, Humphrey; Pridal, Petr (2012). “Old maps online: enabling global access to historical mapping". e-Perimetron, v. 7, n. 2, pp. 73-81.

https://goo.gl/ssARWZ

Temap (2012). "Technology for discovering of map collections". Temap.

http://www.temap.cz/en

Witmer, Alan; Hagan, James; Scaffidi, Brian; Hancock, Jon (2006). "Automated georeferencing of digitized map images". Patentes.

https://www.google.com/patents/US20060041375

\section{Cronología de la Documentación Española}

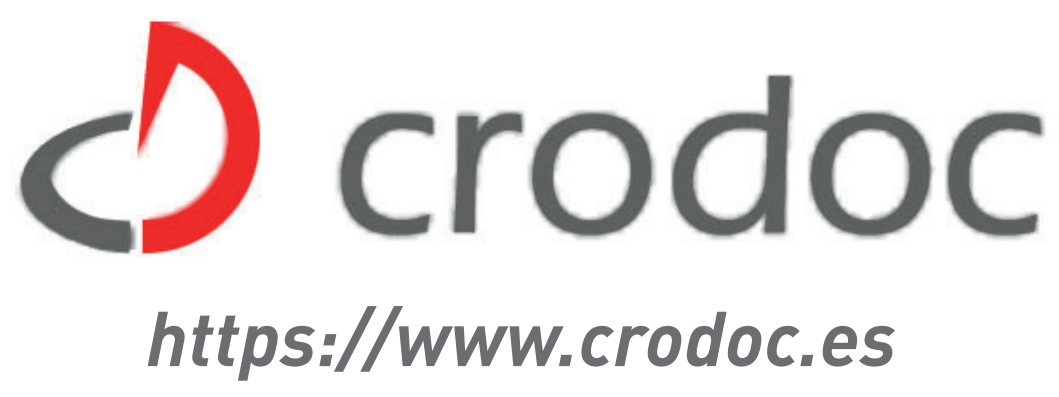

